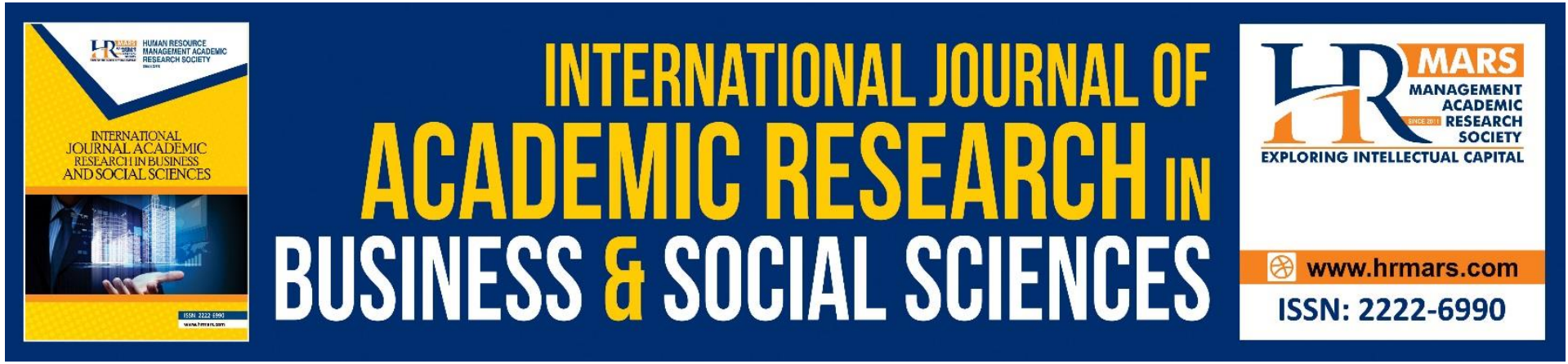

\title{
Malay Language as the Medium of Translation in Smartphone Applications
}

Vijayaletchumy Subramaniam, Kavenia Kunasegran

To Link this Article: http://dx.doi.org/10.6007/IJARBSS/v11-i6/10250

DOI:10.6007/IJARBSS/v11-i6/10250

Received: 18 April 2021, Revised: 20 May 2021, Accepted: 02 June 2021

Published Online: 22 June 2021

In-Text Citation: (Subramaniam \& Kunasegran, 2021)

To Cite this Article: Subramaniam, V., \& Kunasegran, K. (2021). Malay Language as the Medium of Translation in Smartphone Applications. International Journal of Academic Research in Business and Social Sciences, 11(6), 1196-1205.

\section{Copyright: (C) 2021 The Author(s)}

Published by Human Resource Management Academic Research Society (www.hrmars.com)

This article is published under the Creative Commons Attribution (CC BY 4.0) license. Anyone may reproduce, distribute, translate and create derivative works of this article (for both commercial and non-commercial purposes), subject to full attribution to the original publication and authors. The full terms of this license may be seen at: http://creativecommons.org/licences/by/4.0/legalcode

Vol. 11, No. 6, 2021, Pg. 1196 - 1205

http://hrmars.com/index.php/pages/detail/IJARBSS

Full Terms \& Conditions of access and use can be found at http://hrmars.com/index.php/pages/detail/publication-ethics 


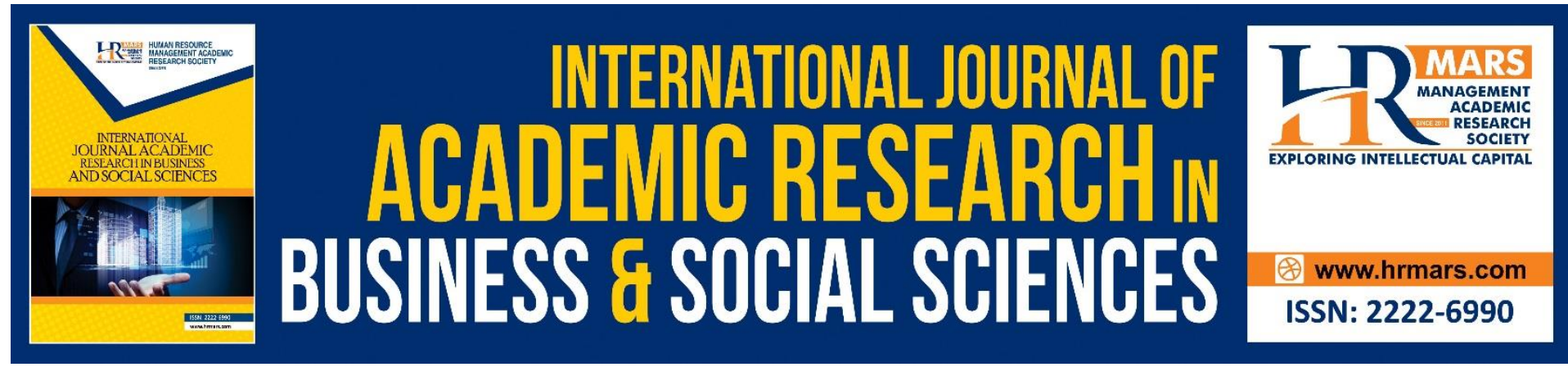

\title{
Malay Language as the Medium of Translation in Smartphone Applications
}

\author{
Vijayaletchumy Subramaniam, PhD, Kavenia Kunasegran \\ Department of Malay Language, Faculty of Modern Language and Communication, \\ Universiti Putra Malaysia, Serdang \\ Email: vletchumy@upm.edu.my, kavenia8@gmail.com
}

\begin{abstract}
This study aims to identify the selection of the language used by smartphone users and analyse the factor of language selection by the smartphone users. The issue of deterioration of the language through smartphones is elaborated so that the parties involved will take this issue seriously, seeing that the Malay Language is the official language of Malaysia. The researchers adapted Nida's theory that was introduced by Eugene Nida (1964). The theory underlines six important aspects in the theory of translation that comprises of recopying of information, similarity not sameness, (formal) similarities, the closest similarity (dynamic), priority of meaning, and the importance of style. Other than that, the priority theory has become the focus in the completion of this study. A total of 30 undergraduate students from the Faculty of Modern Language and Communication, Universiti Putra Malaysia (UPM) were selected as respondents. This study uses two methods, that are the library and fieldwork methods. Survey forms and interview records are the main research tools adopted in this study. The outcome of the analysis reveals that the lack of use of Malay Language as the medium of translation in smartphone applications. Also, this study shows that all the respondents have used the English Language more in the communication technology. This work also shows that the factor that influences the selection of the language includes the fact that they understand the language of choice better, they follow the trend and that it is their mother tongue. Thus, it is anticipated that this study will be able to help the younger generation to empower the Malay Language so that it will become sustainable in this modern era. Future research in this area of study has a lot of potential in examining the relationship of translation, usage of Malay Language, users' preferences and other in-depth factors relating to translation.
\end{abstract}

Keywords: Smartphone Application, Translation, Language Selection, Language Selection Factor, Malay Language, English Language

\section{Introduction}

Language is the main medium of communication. With a sense of understanding established in the language used by these different parties, the process of communication gets done smoothly. Malay Language is the official main language in Malaysia. Although this country has a lot of other languages spoken by various races, like Chinese and Indians, Malaysians have 
become united in speaking the Malay Language as the official language. Malaysia also encompasses hundreds of ethnic groups in Sabah and Sarawak which have their own dialects and languages. Malay Language is confined under the Austronesia language and according to Melebek \& Moain (2005), Malay Language has developed in stages through the passing of time. There are three main stages in the Malay Language, which are the Orthodox Malay Language, Classic Malay Language and Modern Malay Language.

Orthodox Malay Language was used as a lingua franca, which means the language was used as a medium of communication among people in the society. During the reign of Srivijayan government from the $7^{\text {th }}$ century to the $13^{\text {th }}$ century, the classic Malay Language had begun to spread across the transition era, which is after the arrival of Islam in this region in the $13^{\text {th }}$ century, which was then divided into three important eras, namely the Malacca era, JohorRiau era and Acheh era. Moving across the globalisation and the modernisation era today, the changes in the use of Malay Language in this country appears to be more flexible, at par with the technological and economic growth. Several linguistic factors could be playing a part here, like the borrowing of words and suffixes from other languages to Malay Language and vice versa. Nonetheless, there is a specific cause that is highlighted in this study which is the evolution of smartphones by Malaysians and by which impacts the usage of Malay Language. The use of smartphones and language in communication is also very inextricably linked. The use of smartphones also leaves a negative impact towards the language's growth and preservation, if it is ever highlighted.

The history of telephone created by Alexander Graham Bell started in 1876. He created the telephone to connect people all over the world. Referring to the history in Malaysia, the communication system without the analogue wire (ETACS) started in 1989 and Malaysia is the world's largest user of the ETACS portable system where the coverage is $90 \%$ of the areas of the populace. The mobile telephone service Automatic Telephone Using Radio (ATUR) 450 was introduced by Telekom Malaysia (TM) in May 1985. Since then, the technology and designs of the telephone has progressed until today. If we fast forward to the era today, with the creation of smartphones that is sophisticated and with high innovative and creativity processes, it is indeed something that is very appreciated. Smartphones cover various medium for communication, not only SMS (Short Message Service) that was once very popular. Exmples of applications that can be downloaded into the smartphone are Whatsapp, Telegram, Twitter, Facebook, Instagram, and so on. Through these applications, one can communicate more easily and faster, irrespective of time and place.

However, with such speed, Malaysians have ruined the beauty of the existing language. For instance, shortening the words in speeches. According to Hussin (2005), smartphone users will surely shorten their words, and altogether violate the grammar principle or the spelling system on the premise of the limited space characteristic of the smartphone display. There are two types of SMS language corpuses that are not allowed in formal writing, such as official documents and examinations, as readers are confused with the language standard, like short forms in terms of the vocal drop or consonant drop and normal colloquial short forms, like the words 'org' for 'orang', 'aritu' (hari itu), 'gak' (juga), 'tak' (No), 'yg' (yang), 'kuar' (keluar) and 'sape' (siapa). Other than that, there is also the deterioration of the language with the mixture of Malay Language and the English Language like lav(love) and fon (telefon). Supyan Hussin (2005) suggested that Dewan Bahasa dan Pustaka (DBP) should publish a list of abbreviated words so that they do not confuse people.

Through this study, attention and exposure is given to the issue of deterioration of the language through smartphones so that the parties involved will take this issue seriously, 
seeing that the Malay Language is the official language after it gained its independence. The elements of the negative changes seen in Malay Language need to be avoided to empower this language at the international arena, especially when social websites of Malaysians are observed and followed by the world communities, and this can affect the image and perspectives of other people towards this country. This study aims to identify the selection of the language used by smartphone users and analyse the factor of language selection by the smartphone users.

\section{Literature Review}

There have been a lot of studies on language done by local or international scholars. There are issues on the bahasa rojak or mixed languages, the capacity of the Malay Language in the modern world, and the decline of the Malay Language. Nonetheless, none of these titles has specified on the aspect of the empowerment of the Malay Language especially in the world where the technology prevails. This is because in this era, the technology has been exponential and the deterioration of the mother tongue is rampant. Also, Haryati (2013) states that the society communicates a lot more without being face-to-face. They use a great deal of telephone, email, short messages and social media. This will explain the deteriorating state of the language among the younger generation in Malaysia, especially as far as the Malay Language is concerned.

The study of Supyan (2014) seeks to scrutinise the mastery of digital literacy in the language that can be understood because it becomes an important asset to determine the human sustainability in the globalised era. The study involved 230 voluntary respondents whose data were gathered through the questionnaire uploaded in the researcher's blog and distributed using Facebook and Whatsapp Group. Researcher had gone through the trend of the use of the SMS involving the frequency of SMS checked on the phone; not only SMS activity like the mixture of codes between the Malay Language and the English Language, the use of spelling dictionary and the decline of standard language in SMS. The findings directly show that there is still the belief that the SMS code can destruct the standard language.

Noor et.al (2013) had conducted a study to identify the significance of the use of smart phone covering the use of social integration and interaction, information entertainment media and also personal identity. The respondents involved in this study are students at public universities and private universities aged between 18 and 27 years. Among the universities chosen as the place of study are Universiti Putra Malaysia (UPM), Universiti Malaya (UM), Universiti Tun Abdul razak (UNITAR), Universiti Industri Selangor (UNISEL) and Universiti Multimedia Malaysia (MMU). 385 respondents were involved in this study. The study outcome demonstrates that most respondents had chosen personal identity as the most important aspect in their daily lives as because it is very likely that they use other media like the computer, ipod, magazine, newspaper, television and so on when they are looking for information, entertainment also social interaction and integration.

Next, the study of Raha (2013) discusses the world of communication that works together with the development of language and the effects on the Malay community's study area. This study objective is to identify the communication technology used for effective communication among the Malay society, to see the factors that boost the use of the communication technology by the Malay society and to know the significance of the communication technology on effective communication among the Malay society. This study adopts the qualitative method and the data collection method is the face-to-face interview using semi-structured questions and open questions. The data were then analysed using the 
thematic analysis method. Based o the data analysed, there are three main themes which follow the objectives stated. It shows that the communication technology has not been able to replace the face-to-face communication among the Malay people. The communication technology's strengths and weaknesses (particularly smartphones) have been shown in terms of the use of the language and communication of the Malay people in Melaka.

Nur et al. (2011) carried out a study on the acceptance of the use of the foreign language to the Malay Language in the field of Science and Technology. This study was conducted at Universiti Kebangsaan Malaysia (UKM), involving 20 respondents comprising of students of the university. The study methods adopted are library referencing, questionnaire and interview. The study findings include the views and acceptance of the students on the use of the Malay Language in technology. Tay (2011) carried out a study to obtain the data on the linguistics characteristics of the use of SMS language among trainee teachers from the aspect of morphology, especially in terms of the form and the formation of words. 22 trainee teachers from the Batu Lintang Campus Teacher Education Institute were chosen as the sample of the study. 110 SMS text messages were collected and became the corpus of the study and the data analysed through the descriptive qualitative method. The findings had answered the study questions covering the form of words and the types of abbreviated words in SMS language, in terms of the linguistic aspect.

\section{Methodology}

This research is confined to the aims and objectives that explain the issues of the Malay Language as the medium of translation in smartphone applications. The theoretical framework adopted in this study is the theory put forth by Nida (1964). He stated that there are six important aspects in the theory of translation that comprises of recopying of information, similarity not sameness, (formal) similarities, the closest similarity (dynamic), priority of meaning, and the importance of style. Next, the sample of the study is 30 UPM students comprising of various courses and ages. 30 students from the Faculty of Modern Language and Comunication, UPM have served as the sample of our study. The methods used are library method and field method. In the library method, various academic references were referred to get more detailed information. Meanwhile, for the field study, the questionnaire form containing 4 main sections namely the demographic section, the Likert scale section, objective section and finally the open ended question section will be distributed to respondents at random. Interviews were also carried out with the respondents. The outcome of the interview was recorded in the form of transcriptions. The data obtained is transferred into the SPSS software and analysed qualitatively and quantitatively. The study data is presented visually in the form of pie charts, graphs or tables. 


\section{Findings and Discussion}

The language selection of smartphone users

Section I: Demography
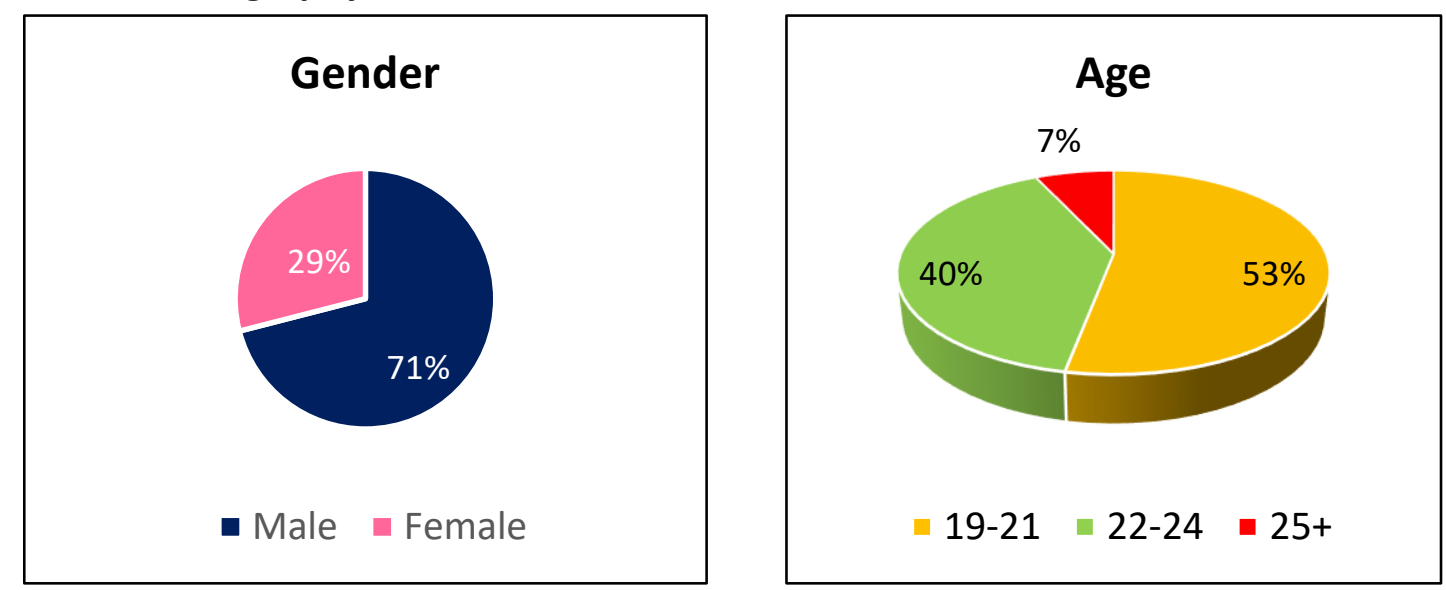

Diagram 1: Section I (Demography)

According to Diagram 1 above, the researchers carried out a field study involving 30 respondents comprising of 14 male and 16 female respondents to to analyse the language selection of smartphone users and the influencing factors, The age range is from 19 to 21 years old with 16 respondents, 22 to 24 with 12 respondents, and 25 and above with 2 respondents. All the respondents are from English Literature course from the Faculty of Modern Language and Communication. The data collected both qualitative and quantitative. Researchers analyzed using objective and open ended questions.

Section II: Language Selection

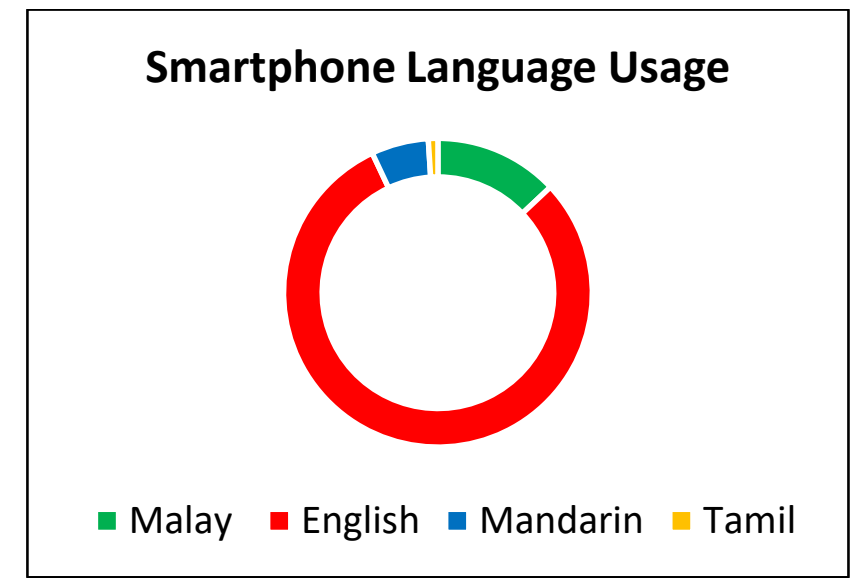

Diagram 2: Section II (Question 1) 
Based on the diagram, it is found that 24 respondents, or $80 \%$ had chosen the English Language for the first question which is the selection of their language when they use their smartphone. Meanwhile, 4 respondents (13\%) chose Malay Language and 2 chose (6\%) chose the Chinese Language as their language of choice. From the study outcome, researcher finds that the majority or $70 \%$ out of 24 respondents chose English were students aged 19 to 24 years.

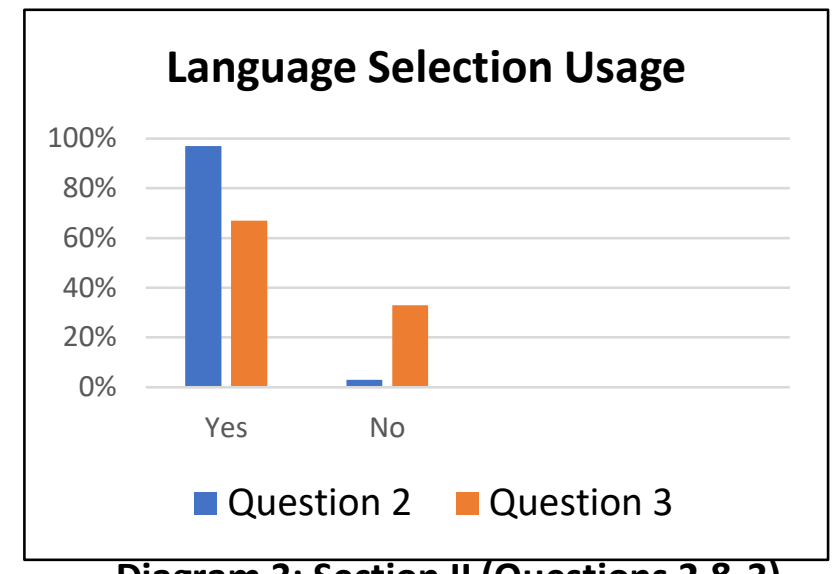

Diagram 3: Section II (Questions 2 \& 3)

Based on Diagram 3, 29 (97\%) respondents had chosen 'Yes' for the second question which is, is the language selected helping them in their daily activities and only 1 respondent answered 'No' (3\%). Researcher also finds that the majority of the respondents who answered 'Yes' for Question 1 are respondents who had chosen English as their language of choice. In the meantime, for the third question, does the language chosen contribute to the empowerment of the Malay Language, a total of 20 (67\%) respondents answered 'No' and 10 (33\%) respondents answered 'Yes'. The majority of them who had answered 'No' were also the ones who chose English Language as their chosen language and the majority who answered 'Yes' were the respondents who chose the Malay Language as their language of choice. It is concluded that, although the subjects are more comfortable using English Language as it is already part of their daily activities, they also realized that it does not give any contribution to the empowerment of Malay Language. Thus, the reason given by the respondents is that the use of the English Language has created a mixture of languages used by the majority. The mixture of the language or the 'bahasa rojak' refers to the blend of languages that has been adopted such as Malay Language and the English Language. Respondents also found that the weakness that thrives in their skills and understanding also occurs when they use this bahasa rojak as they are comfortable with the vocabulary in the English Language. 


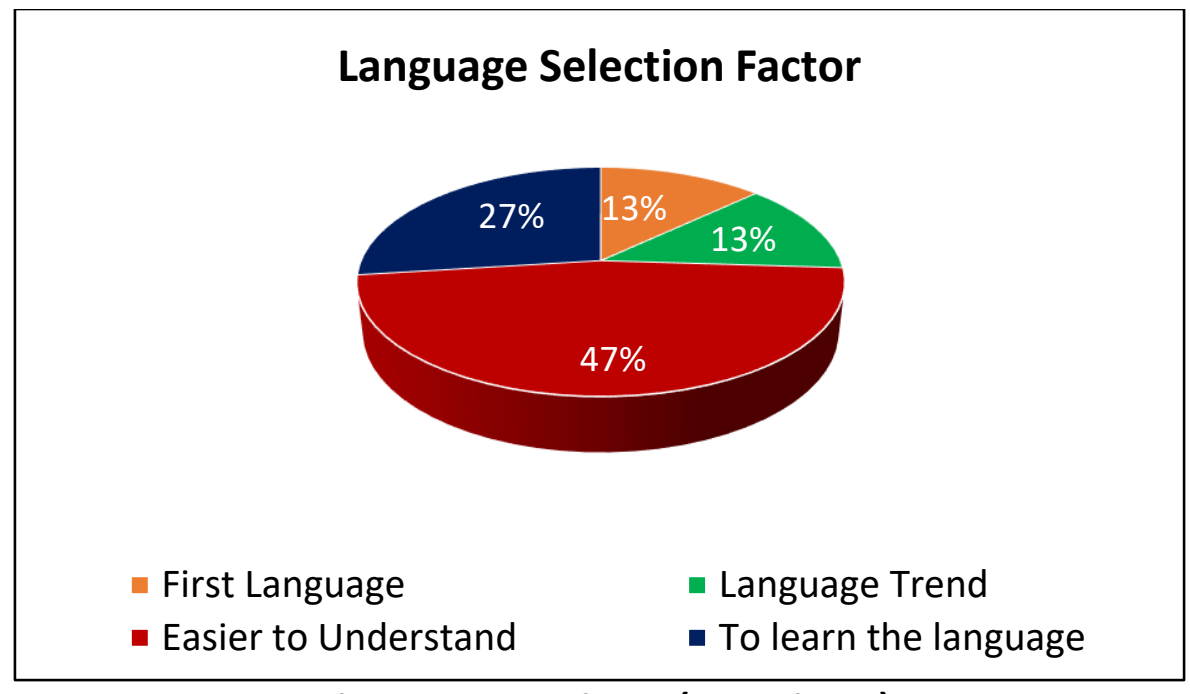

Diagram 4: Section II (Question 4)

Based on Diagram 4 above, 14 respondents (47\%) had chosen the factor 'it is easier to understand' for the fourth statement, which is what is the factor that causes them to choose the language. A total of 8 respondents (27\%) had chosen 'to learn the language', whereas 4 (13\%) respondents had chosen 'first language/ mother tongue' and 4 (13\%) respondents chose 'follow the passing of time/ language trend'. The majority who had chosen 'mother tongue' comprised of students who chose Malay Language and the Mandarin language as their language of choice. For those who chose 'it is easier to understand', the majority had chosen the English Language as their language of choice. Thus, the researcher finds that, although the respondents have their own mother tongues, they still chose English Language as their language of choice because it is simpler to understand. English Language has become the language of technology today as it is a language that it is easy to understand by the majority of the global population. Globalisation also plays its role in this issue.

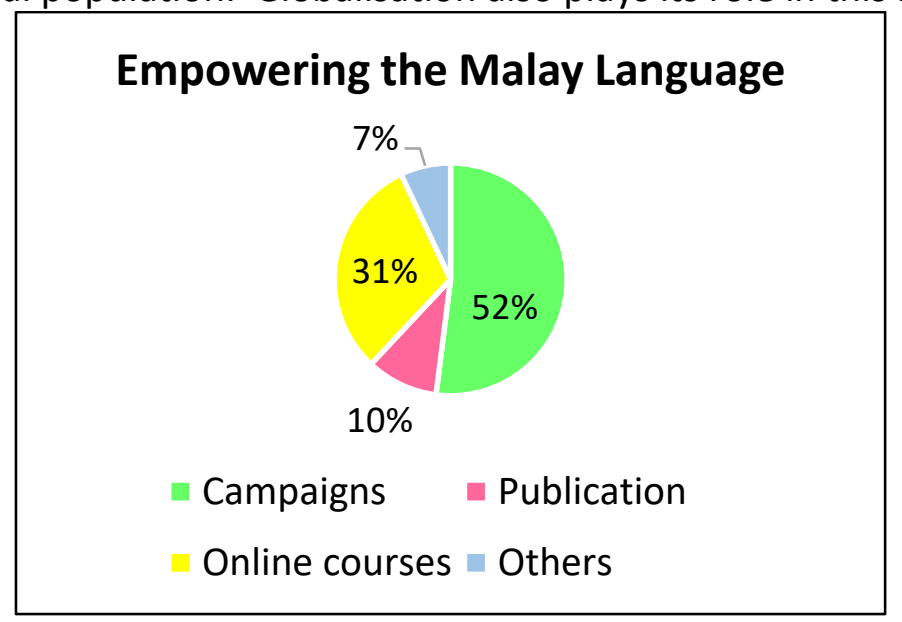

Diagram 5: Section II (Question 5)

The fifth statement refers to the effort made to empower the Malay Language in the technology use today. Based on Diagram 5, a total of $52 \%$ has the opinion that planning campaigns for this purpose helps in the long run. 9 other respondents felt online language courses at the higher learning institutes play a bigger role in the language empowerment (31\%). Apart from that, 3 respondents (10\%) chose more publications on more technologyrelated translation dictionaries from foreign languages to Malay Language. Meanwhile, 2 
more respondents had given their opinion which is to instil the use of the Malay Language from young and also to extract Malay Language terms that are easy to understand for users (7\%).

\section{Conclusion}

In summary, this study seeks to identify the choice of the language used by smartphone users and to analyse the factor of the language selection by said users. In this study, respondents' opinion on the use of the Malay Language in smartphone applications was sought and most of them stated that the English Language is easier for them to grasp because they have been exposed to the words in the English Language in every aspect of their lives. This clearly shows how the Malay Language is less spoken and used in the aspect of life. Other than that, the theory by Eugene Nida (1964) which highlights the importance of meaning has served as the focus of this study. In this aspect, the content of the message is important and the translation must undergo a radical change so that the information delivered can be retained. In this study, there are several measures that need to be recommended so that the Malay Language can be empowered especially among the generations today. Among the steps that can be Cited include Malay language awareness campaigns, more related translation publications on Malay Language and to instill the interest in the younger generation to gain knowledge on translation.

To sum up, the use of Malay Language as a medium of translation in smartphone applications must be balanced out so that it will benefit users in their daily lives. Although English Language is always spoken by Malaysians, we must always uphold our mother tongue so that it will not lose its' originality in the long run. It is hoped that the balance in using the language must be preserved and maintained the best way possible.

\section{References}

Awang, S. (2013). Penterjemahan Memperkasakan Malay Language Sebagai Language IImu. Dewan Bahasa dan Pustaka.

Chan, S. W. (2012). Teknologi Terjemahan: Dahulu, Sekarang dan Masa Depan. Jurnal Terjemahan Alam \& Tamadun Melayu 4:1 (2012) 25 - 44.

Hassan, A. (2009). Ke Luar Jendela. Kuala Lumpur: Dewan Bahasa dan Pustaka.

Haryati, A. (2013). Generasi Y dan Budi Language yang Semakin Terpinggir. The Malaysian Insider.

Nida, E. A., \& Taber, E. L. (1974). The theory and practice of translation. Leiden: E.J. Brill, Leiden.

Raha, R. (2013). Komunikasi Efektif Melalui Media Perantaraan Dalam Kalangan Masyarakat Melayu: Satu Kajian Kes di Melaka dalam Institut Pemikiran dan Kepimpinan Melayu (IMPAK). Universiti Teknologi MARA.

Supyan, H. (2006). Perimbangan Pembangunan Language SMS dan Pelestarian Language Kebangsaan. Prosiding Persidangan Antarbangsa Pengajian Melayu 2006: Warisan Seni Budaya Melayu - Pelestarian dan Pembangunan. Kuala Lumpur APM-Universiti Malaya, 275-284.

Supyan, H. (2005). Korpus language SMS: Antara kreativiti dan ancaman kepada Bahasa. Prosiding Seminar Kebangsaan Linguistik SKALI 05. Kajian Bahasa dan Korpus: Dimensi Linguistik Semasa. Bangi: FSSK-UKM and DBP. 
Supyan, H. (2013). Pengurusan maklumat dan ilmu dalam transformasi dan pembangunan sosial. International Conference on Social Sciences and Humanities, ICOSH 2013. Universiti Kebangsaan Malaysia. 13-14 Dec 2011.

Supyan, H. (2014). Kelestarian Insan Dan Bahasa Dalam Arus Telekomunikasi Global. Universiti Kebangsaan Malaysia.

Tay, M. G. (2011). Analisis Linguistik Terhadap Penggunaan Bahasa SMS Dalam Kalangan Guru Pelatih. Volume 10. Research Journal. Batu Lintang IPG Campus. 